\title{
INTERRELATION BETWEEN TOURIST RISK PERCEPTION AND DESTINATION IMAGE AND REVISIT INTENTION EAST LOMBOK POST EARTHQUAKE
}

Ni Wayan Marsha Satyarini' ${ }^{1}$ Tamjuddin Tamjuddin², Ramdhan Kurniawan ${ }^{3}$

wayanmarsha@ecampus.ut.ac.id 1 , tamjuddin@ecampus.ut.ac.id ${ }^{2}, \underline{\text { ramdhan-kurniawan@ecampus.ut.ac.id }}^{3}$ a,b,cProgram Studi S1 Manajemen, Fakultas Ekonomi, Universitas Terbuka, Indonesia

\begin{abstract}
This research developed of tourist risk perception and destination image and revisit intention. The research also focused how tourists are influenced by natural disasters and provides empirical evidence to predict the hypothesis models. The results of a study of 230 of local and international tourists visit to East Lombok post the earthquake. This study examining: (1) the effect of risk perception and destination image (2) the effect of destination image and revisit intention (3) the effect of risk perception and revisit intention post natural disaster. Results as expected, all results had positive and significant relation between variables. This research used SEM-AMOS as analysis method.
\end{abstract}

Keyword: earthquake, natural disaste, risk perception, destination image, revisit intention

\section{INTRODUCTION}

\section{Background}

Tourism industry is also very vulnerable to internal issues, such as crimes, social and political instabilities, and external threats such as war, terrorism, natural disasters, contagious diseases which may harm destination image [1]. This scenario may pose a different challenge for marketers to apply effective positioning strategy for tourist destinations impacted by natural disasters due to increased perceived risks [2]. World Travel and Tourism Council (WTTC) states that tourist destinations with terrorist attack can recover faster than those with natural disasters. Natural disasters are unavoidable [3]. In Indonesia, in the past 18 years, major scale natural disasters, especially earthquakes and tsunamis, have happened 12 times (Table 1). The geographic location and geographic characteristics of Indonesia is a challenge for the tourism industry because continuous tectonic activities often trigger earthquakes and tsunamis, while volcanic activities cause earthquakes and eruptions. This situation is worsened by the fact that disaster management is still difficult in Indonesia, especially when it comes to the tourism industry [4]. Phenomena such as natural disasters, terrorism, etc. often increased the risk level perceived by tourists [5], which in the end worsens the destination image as a popular destination.

TABLE 1 Earthquake And Tsunami In Indonesia 2000 - 2018

\begin{tabular}{|l|l|l|l|l|l|}
\hline No. & Location & Disaster & \multicolumn{1}{|c|}{ Date } & Magnitude & Fatalities \\
\hline $\mathbf{1}$ & Sumatera & Gempa & $\begin{array}{l}4 \text { June } \\
2000\end{array}$ & 7.9 & 103 \\
\hline $\mathbf{2}$ & Sumatera & $\begin{array}{l}\text { Earthquake } \\
\text { \& Tsunami }\end{array}$ & $\begin{array}{l}26 \\
\text { December } \\
2004\end{array}$ & $9.1-9.3$ & 165,945 \\
\hline $\mathbf{3}$ & Sumatera & Earthquake & $\begin{array}{l}28 \text { March } \\
2005\end{array}$ & 8.6 & 1,313 \\
\hline $\mathbf{4}$ & Java & $\begin{array}{l}\text { Earthquake } \\
\text { \& Tsunami }\end{array}$ & $\begin{array}{l}26 \text { May } \\
2006\end{array}$ & 6.3 & 5,749 \\
\hline $\mathbf{5}$ & Java & $\begin{array}{l}\text { Earthquake } \\
\text { \& Tsunami }\end{array}$ & $\begin{array}{l}17 \text { July } \\
2006\end{array}$ & 7.7 & 802 \\
\hline $\mathbf{6}$ & Sumatera & $\begin{array}{l}\text { Earthquake } \\
6 \text { March } \\
2007\end{array}$ & 6.4 & 68 \\
\hline $\mathbf{7}$ & Sumatea & $\begin{array}{l}\text { Earthquake } \\
\& \text { Tsunami }\end{array}$ & $\begin{array}{l}25 \\
\text { October } \\
2010\end{array}$ & 7.8 & 408 \\
\hline $\mathbf{8}$ & Sumatera & Earthquake & $\begin{array}{l}7 \\
\text { December } \\
2016\end{array}$ & 6.5 & 104 \\
\hline
\end{tabular}




\begin{tabular}{|l|l|l|l|l|l|}
\hline $\mathbf{9}$ & Lombok & Earthquake & $\begin{array}{l}\text { 5 August } \\
2018\end{array}$ & 6.9 & 563 \\
\hline $\mathbf{1 0}$ & Lombok & Earthquake & $\begin{array}{l}19 \text { August } \\
2018\end{array}$ & 6.3 & 12 \\
\hline $\mathbf{1 1}$ & $\begin{array}{l}\text { Central } \\
\text { Sulawesi }\end{array}$ & Earthquake & $\begin{array}{l}28 \\
\text { September } \\
2018\end{array}$ & 7.5 & 1,948 \\
\hline $\mathbf{1 2}$ & $\begin{array}{l}\text { West } \\
\text { Java \& } \\
\text { Lampung }\end{array}$ & Tsunami & $\begin{array}{l}22 \\
\text { December } \\
2018\end{array}$ & - & +400 \\
\hline
\end{tabular}

Source: www.mercycorps.org/articles/quick-facts-indonesia-disasters.

Positive image of a destination positively affects tourists' revisit intention the location in the future [6]. The success of a tourism industry really depends on tourist satisfaction and their desire to revisit a tourist destination and they can be walking marketing by spreading it using word of mouth to tourists and potential customers [7]. Security is one of the important factors for tourists to decide to visit a tourist destination. Tourism is especially sensitive to security issues. Changes in the world may cause change in tourist purchasing behaviour. Security issues have significant effect on tourist purchasing behaviour and decision making process [8].

\section{Formulation of Problems}

From the facts in the background above, the main problems faced by East Lombok are:

a. How does tourist risk perception affect destination image?

b. How does destination image affect revisit intention?

c. How does tourist risk perception affect revisit intention

\section{LITERATURE REVIEW}

\section{Risk and Tourism}

Risk is a word that has different meanings to different people [9]. According to Aven and Renn, risk is uncertainty on the severity of an event and consequence (or of an outcome) of activity related with something appreciated by human [10]. Risk is defined as something unplanned or something which can't be ascertained from event, due to the vulnerability or external or internal factor, and is an integral and inseparable part of business [11].

According to Hasan et al., the risk dimension is commonly used to affect tourist behaviours when they visit tourist attractions, a resource, and process [12]. Risk dimension is classified based on the significance perceived by tourism in different tourism processes. We know that physical risk is the most important for natural tourism, followed by performance risk, psychological risk, financial risk, and natural disaster risk. Second, equipment is the most important for cultural tourism, followed by physical risk, performance risk, psychological risk, and terrorism risk. Third, tourist may care more about financial risk when they purchase tourism commodity and participate in cultural tourism activities. Lastly, for adventure tourism, equipment risk is the biggest concern of tourists, followed by physical risk, financial risk, social risk, and performance risk

\section{Risk Perception}

The meaning of risk perception according to Teng is a customer perception on uncertainty and bad consequence of an activity [13].

Risk perception in tourism can be separated by individual characteristic of every tourist $[14,15]$. Reisinger and Mavondo's definition of perceived risk is vacationing tourist may not realize their own assessment on potential on risks they will face [16]. In other words, tourists may not fully understand risk probability, although they may have many ideas on the possible risks they may face

\section{Destination Image}

Broadly speaking, image refers to mental image people make to interpret their environments [17]. Destination image can be described using expression on overall objective knowledge, prejudice, impression, emotional thoughts and imagination and individual on a certain location. These images are important because they significantly affect the decision 
making behaviour of potential tourists and satisfaction level based on tourist experience [18]. Another view is destination image is an interactive system of thoughts, opinions, feelings, visualization, and intention to a destination [19]. It's conclude that the destination image of a tourist destination plays an essential role in the success of the tourist destination. It's because the destination image of a tourist destination has multidimensional effects on both local community and tourists. Perception on tourist destination image affects satisfaction and intention to visit related tourist attractions in the future, which obviously depend on the ability of tourist destination to give positive unforgettable experience during the tour [20]. Destination image consists of two components which are cognitive image and affective image [21]. Cognitive component refers to one's belief on the characteristic or attribute of tourist destination [22,23], while affective component is individual's feelings on tourist destination [24].

\section{Cognitive Image}

The cognitive image of a destination should consist of individual perception of attribute [25]. The components of cognitive image according to Martin \& del Bosque include [26]:

a. Infrastructure and socio-economic environment.

b. Atmosphere.

c. Natural attraction.

d. Cultural attraction.

\section{Affective Image}

Affective Image refers to feelings and emotions raised by tourist destination [27]. Affective image has 3 dimensions $[21,28]$ : fun destination, interesting destination, and relaxing destination.

\section{Behavioral Intention}

Behavioural intention is tourist behavioural tendency after doing touring activity to revisit in the future and recommend it to others, related with Theory of Planned Behaviour Model (TPB) [29]. This theory states that attitude to behaviour, subjective norms, and perceived behavioural control form individual or tourist intention and behaviour. Beneficial behavioural intention often represents creative customer loyalty. Moreover, loyal customer tends to recommend friends, relatives or other potential customers to a product/service by acting as a word of mouth advertising agent [30].

\section{Revisit Intention}

The satisfaction and positive image experienced by tourist will have two main benefits. First, future tourist will use this positive image as a reference and reflect them to make decision in choose destination to visit. Second, tourist who is fully satisfied in the first trip is more likely to come to the location against with more friends and suggest and recommend the place to people they know (see Figure 1) [31].

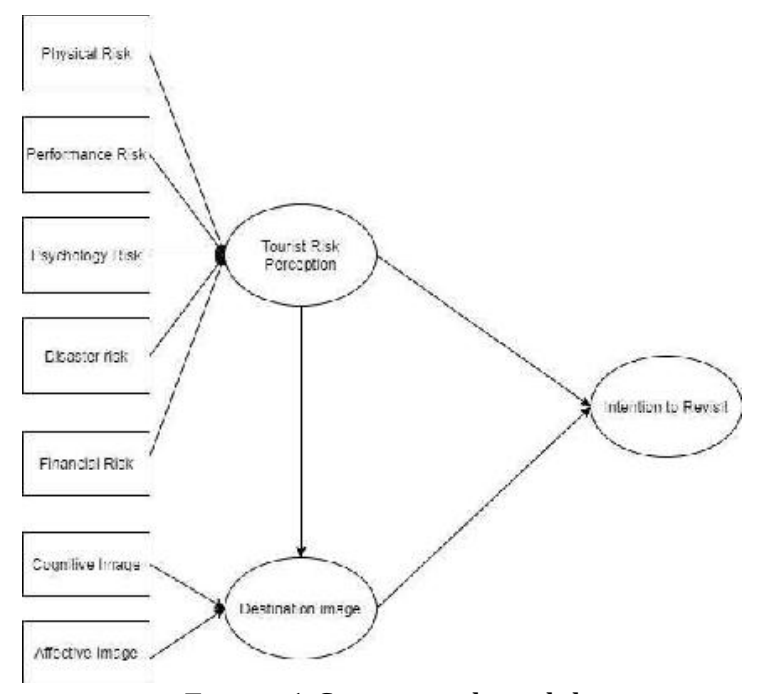

Figure 1 Conceptual model 


\section{Hypothesis}

Based on the framework above, the hypotheses in the present study are:

a. There is positive and significant relation between risk perception and destination image after natural disaster.

b. There is positive and significant relation between destination image and revisit intention after natural disaster.

c. There is positive and significant relation between risk perception and revisit intention after natural disaster

\section{METHODS}

\section{Research Design}

The present study was a study with tourism review and focuses on behavioural study of tourist who visited East Lombok post earthquake. The purpose of the present study was determining and analysing the effect of tourist risk perception and destination image on revisit intention post earthquake in East Lombok. The research used descriptive research approach.

The present study used quantitative method, which is a research methodology that attempt to quantify data and apply certain statistical analysis related with data collection method, sample design and construction of data collection instrument [32]. Data collection was performed by collecting primary data using questionnaire and performing in-depth interview with tourism actors.

\section{Data Collection}

The population in the present study was tourists who visited East Lombok. The sample was tourists who visited East Lombok for the first time or more. The sampling method was nonprobability sampling. Nonprobability sampling relies on personal judgment of the researcher in the chance to select sample element [33].

\section{Analysis Method}

The data collection of the questionnaire result can be categorized into 3 steps, i.e. preparation, tabulation and data application on research approach. Since the present study was descriptive and verification, the data analysis used 2 approaches, i.e. descriptive analysis method and verification analysis. Descriptive analysis was used by compiling a frequency distribution table to determine overall respondent characteristics and respondent assessment on every research variable indicator. Meanwhile, verification analysis to test the hypotheses used in the present study were Structural Equation Modelling (SEM)-AMOS software.

\section{RESULTS AND DISCUSSION}

Testing the suitability of the research model using goodness of fit models performed as follows Table 2:

\begin{tabular}{|l|l|c|r|}
\hline \multicolumn{1}{|c|}{$\begin{array}{c}\text { Goodness of } \\
\text { Fit Measures }\end{array}$} & $\begin{array}{c}\text { Recommended } \\
\text { Acceptance } \\
\text { Limits }\end{array}$ & Value & Judgment \\
\hline GFI & $>0,80$ or close to 1 & 0,862 & $\begin{array}{r}\text { Acceptable } \\
\text { Fit }\end{array}$ \\
\hline RMSEA & $<0,08$ & 0,028 & $\begin{array}{r}\text { Acceptable } \\
\text { Fit }\end{array}$ \\
\hline CFI & $>0,90$ & 0,992 & $\begin{array}{r}\text { Acceptable } \\
\text { Fit }\end{array}$ \\
\hline NFI & $>0,80$ & 0,936 & $\begin{array}{r}\text { Acceptable } \\
\text { Fit }\end{array}$ \\
\hline TLI & $>0,90$ & 0,991 & $\begin{array}{r}\text { Acceptable } \\
\text { Fit }\end{array}$ \\
\hline
\end{tabular}

The results of the goodness of fit model such as the GFI, RMSEA, CFI, NFI, and TLI values appear to meet the specified conditions, indicating that the formation of the conceptual framework is in accordance with the statement items. Seen in Figure 2 Structural Equation Model as follows. 


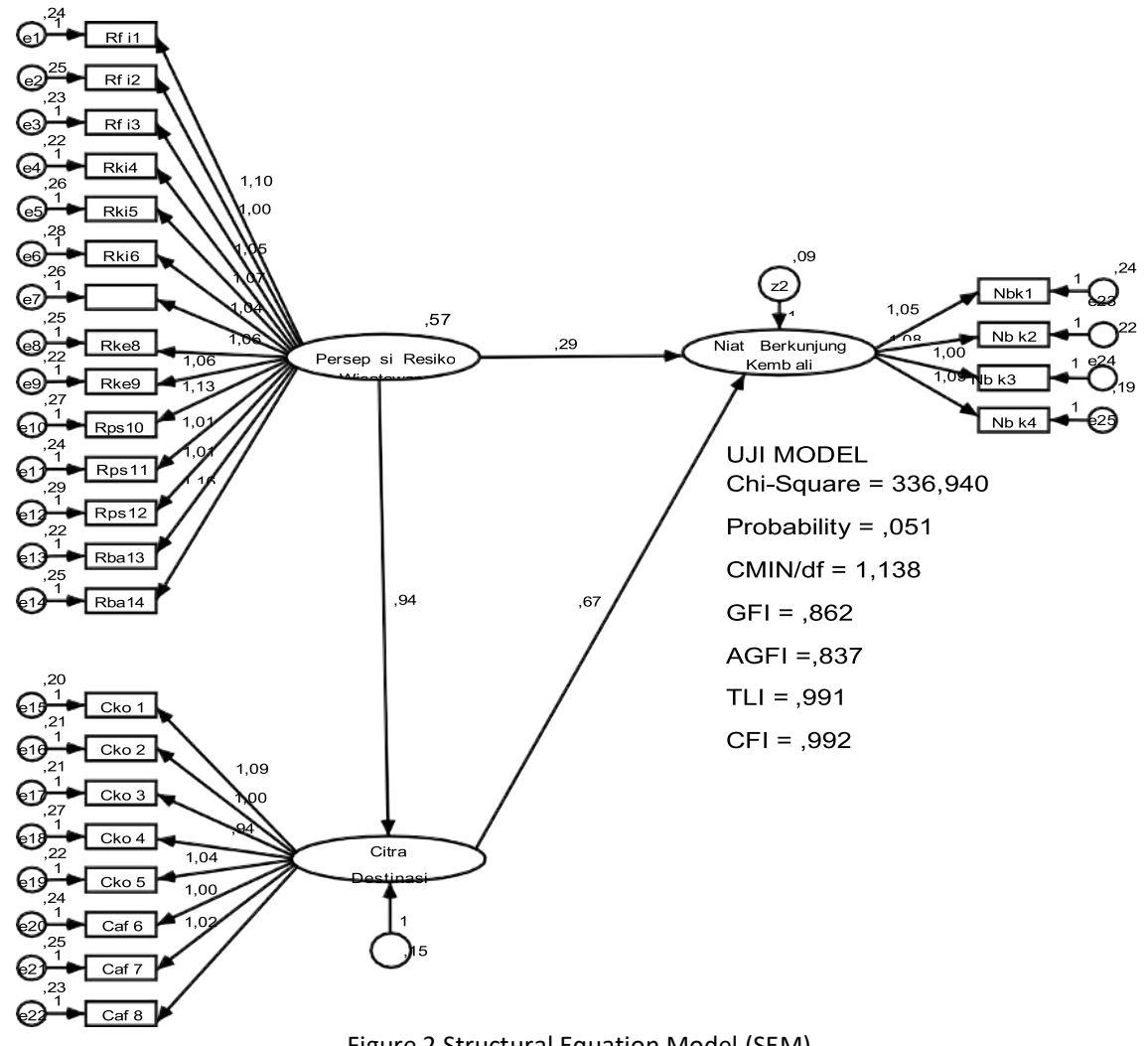

Figure 2 Structural Equation Model (SEM)

Data analysis was obtained from test result on tourist risk perception, destination image, and revisit intention. This was done by seeing the significance value of each relation. T-test was done was checking probability value (p-value), so if p- value $<0.05$ the hypothesis is supporter. Hypothesis test result is shown in Table 3 below:

Table 3 Hypothesis Test Result

\begin{tabular}{|l|l|l|l|}
\hline \multicolumn{1}{|c|}{ Hypothesis } & $\begin{array}{c}\text { Standardized } \\
\text { Coefficient Beta ( } \beta)\end{array}$ & p-value & Decision \\
\hline $\begin{array}{l}\text { H1: } \\
\text { tourist risk perception } \\
\text { destination image }\end{array}$ & 0,942 & 0,000 & H1 Supported \\
\hline $\begin{array}{l}\text { H2: } \\
\text { destination image } \\
\text { revisit intention }\end{array}$ & 0,667 & 0,000 & H2 Supported \\
\hline $\begin{array}{l}\text { H3: } \\
\text { tourist risk perception } \\
\text { revisit intention }\end{array}$ & 0,293 & 0,002 & H3 Supported \\
\hline
\end{tabular}

Source: Data processed using AMOS Version 7 (Data Process Attached)

\section{Hypothesis 1}

Ho1: Tourist risk perception doesn't affect destination image.

Ha1: Tourist risk perception affects destination image.

Based on the data analysis in the table above, the significant level is 0.000 and standardized coefficient beta of the effect of tourist risk perception on destination image is 0.942 . Tourist risk perception affected destination image. Therefore, the first hypothesis that tourist risk perception affects destination image was supported. It showed that although tourists are worried about environmental change after the earthquake, they still believed that East Lombok was friendly for tourists after the earthquake

\section{Hypothesis 2}

Ho2: Destination image doesn't affect revisit intention.

Ha2: Destination image affects revisit intention.

Based on the data analysis in the table above, the significant level is 0.000 and standardized coefficient beta of the effect of destination image on revisit intention is 0.667 . Destination image affected revisit intention. 
Therefore, the second hypothesis that destination image affects revisit intention was supported. It showed that East Lombok was still friendly for tourists, so they would recommend East Lombok to their friends and family.

\section{Hypothesis 3}

Ho3: Tourist risk perception doesn't affect revisit intention.

Ha3: Tourist risk perception affects revisit intention.

Based on the data analysis in the table above, the significant level is 0.002 and standardized coefficient beta of the effect of tourist risk perception on revisit intention is 0.293 . Tourist risk perception affected revisit intention. Therefore, the third hypothesis that tourist risk perception on revisit intention was supported. It showed that although tourists were worried about environmental change after the earthquake, East Lombok still met the tourists' expectation compared with other tourist destinations in Lombok

\section{Research Result Discussion}

The hypothesis analysed the effects of tourist risk perception on destination image, destination image on revisit intention, and tourist risk perception on revisit intention.

H1: Tourist risk perception affects destination image.

The research result supported the result of the study by Hasan et al. in which p-value < alpha 0.001 with beta value of 0.198 , meaning tourist risk perception significantly affects improving destination image for tourists [12].

H2: Destination image affects revisit intention.

The research result didn't support the research result by Artuger et al. in which p-value is 0.000 with beta value of 0.84 , meaning destination image could increase revisit intention [21].

H3: Tourist risk perception affects revisit intention.

The research result supported the result of the study by Cetinsoz and Ege in which p-value is 0.013 with beta value of 0.20 , meaning tourist risk perception could create revisit intention [34].

\section{CONCLUSION}

This research study risk perception, destination image and revisit intention. The major focus on this study was to examine mediating roles of destination image, between risk perceptions and revisit intention to East Lombok post Earthquake. Our research highlights the results of this research:

1. Tourists are worried about environmental changes after the natural disaster but they still believe that East Lombok creates a friendly environment for tourists after the natural disaster.

2. East Lombok has a friendly environment for tourists so tourists will recommend East Lombok to friends and family.

3. Tourists are worried about environmental changes after the natural disaster but East Lombok still meets tourist expectation compared to other tourist destinations in East Lombok.

Therefore research in the future should more depth to understanding interrelation between risk perception and destination image, and conducted with qualitative and quantitative method are warranted as it will provide more data from respondents thoughts. 


\section{REFERENCES}

A. Beerli and J.D. Martín. 2004. Factors Influencing Destination Image. Annals of Tourism Research, vol. 31, no. (3), pp. 657-681.

A. Lepp and H. Gibson. 2003. Tourist Roles, Perceived Risk And International Tourism. Annals of Tourism Research, vol. 30 , no. (3), pp. 606- 624 .

A.D. Tasci. 2007. Assessment Of Factors Influencing Destination Image Using A Multiple Regression Model. Tourism Review, vol. 62, no. (2), pp. 23-30.

B. Court and R.A. Lupton. 1997. Costumer Portfolio Development: Modelling destination Adapters, Inactives, and rejecters. Journal of Travel Researchm, vol. 36, no. (1), pp. 35 - 43.

B.C. Çetinsöz and Z. Ege. 2013. Impacts of perceived risks on tourists' revisit intentions. Anatolia, vol. 24, no. (2), pp. 173-187.

C.M. Echtner and J.R.B. Ritchie. 1993. The Measurement Of Destination Image: An Empirical Assessment," Journal of Travel Research, vol. 31, no. (4), pp. 3-13.

E. Banks. 2005. Catastrophic Risk: Analysis and Management. US: John Wiley \& Sons Ltd.

E. Kneesel, S. Baloglu, and M. Millar. 2010. Gaming destination images: Implications for branding. Journal of Travel Research, vol. 49, no. (1), pp. 68-78.

E. Ridrasih. 2018. Tourists' Perceived Risk and Image of Destinations Prone to Natural Disasters: The Case of Bali and Yogyakarta, Indonesia. HUMANIORA, vol. 30, pp. 192-203.

G. Schiffman and L. Kanuk. 2000. Consumer Behavior. NJ: Prentice Hall, Inc., Englewood Cliff.

H. Kim and S.L. Richardson. 2003. Motion Picture Impacts On Destination Images," Annals of Tourism Research, vol. 30, no. (1), pp. 216-237.

H. Zhang, X. Fu, L.A. Cai, and L. Lu. 2014. Destination Image And Tourist Loyalty: A Meta-Analysis. Tourism Management, vol. 40, pp. 213-223.

H.S. Martı'n and I.A.R. del Bosque. 2008. Exploring The Cognitive- Affective Nature Of Destination Image And The Role Of Psychological Factors In Its Formation. Tourism Management, vol. 29, pp. 263-277.

J. Adams. 2014 . Managing Risk: Framing Your Problems. Boeringer Ingelheim Alumni Seminar, Schloss Gracht, pp. 9-11.

Jahari, S.A. and Teng, C.Y. 2012. The Effects Of Perceived Risks On Destination Image And intention to revisit Disaster Stricken Japan: A Conceptual Paper. 26th Annual Australian and New Zealand academy of management conference: Managing for volatility and instability, pp. $1-22$.

K. Ryu, B.M. Bordelon, and D.M. Pearlman. 2013. Destination-image recovery process and visit intentions: Lessons learned from Hurricane Katrina. Journal of Hospitality Marketing \& Management, vol. 22, no. (2), pp. 183203.

M.E. Korstanje. 2009. Re-Visiting Risk Perception Theory In The Context Of Travel. E-Review of Tourism Research (eRTR), vol. 7, no. (4), pp. 68-81.

M.K. Hasan, A.R. Ismail, and M.F. Islam. 2017. Tourist risk perceptions and revisit intention: A critical review of literature. Cogent Business \& Management, vol. 4, no. (1), p. 1412874. 
N. Malhotra. 2010. Introduction: Analyzing Accumulated Knowledge and Influencing future Research. N. Malhotra, (Ed.) Review of Marketing Research (Review of Marketing Research, Vol. 7). Bingley, UK: Emerald Group Publishing Limited, pp. xiii-xxviii.

S. Artuğer, B.C. Çetinsöz, and I. Kılıç. 2013. The effect of destination image on destination loyalty: An application in Alanya. European Journal of Business and Management, vol. 5, no. (13), pp. 124-136.

S. Artuğer. 2015. The Effect of Risk Perceptions on Tourists' Revisit Intention. European Journal of Business and Management Paper, vol. 7, no. (2), pp. $36-43$.

S. Baloglu and K.W. McCleary. 1999. A Model Of Destination Image Formation. Annals of Tourism Research, vol. 26, no. (4), pp. 868-897.

S. Coban. 2012. The Effects Of The Image Of Destination On Tourist Satisfaction And Loyalty: The Case Of Cappadocia. European Journal of Social Science, vol. 29, no. (2), pp. 222-232.

S. Pike and C. Ryan. 2004. Destination Positioning Analysis Through a Comparison of Cognitive, Affective, and Conative Perceptions. Journal of Travel Research, vol. 42, no. (4), pp. 333-342.

S. Shoemaker and R.C. Lewis. 1999. Customer Loyalty: The Future Of Hospitality Marketing. International Journal of Hospitality Management, vol. 18, pp. 345-370.

S.D.F. Lopes. 2011. Destination image: Origins, Developments and Implications. Pasos. Revista de Turismo y Patrimonio Cultural, vol. 9, no. (2), pp. 305-315.

S.R. Cipta and N. Farida. 2018. Pengaruh Destination Image, Fasilitas Wisata, Dan Perceived Value Terhadap Behavioral Intentions. Jurnal Ilmu Administrasi Bisnis, vol. 7, no. (3).

Sönmez, S.F., Apostolopoulos, Y., and Tarlow, P. 1999. Tourism In Crisis: Managing The Effects Of Terrorism. Journal of Travel Research, vol. 38, pp. 13-18

T. Aven and O. Renn. 2009. On Risk Defined As An Event Where The Outcome Is Uncertain. Journal of Risk Research, vol. 12, pp. 1-11.

T. Lee. 2005. A Structural Model to Examine how Destination Image, Attitude and Motivation affects the Future Behavior of Tourists. Leisure Sciences, vol. 31, no. (12), pp. 215-236.

W. Teng. 2005. Risks Perceived By Mainland Chinese Tourists Towards Southeast Asia Destinations: A Fuzzy Logic Model. Asia Pacific Journal of Tourism Research, vol. 10, no. (1), pp. 97-115.

W.S. Roehl and D.R. Fesenmaier. 1992. Risk perceptions and pleasure travel: An exploratory analysis. Journal of Travel Research, vol. 30, pp. 17-26.

WTTC, World Travel and Tourism Council. London, UK: WTTC.

Y. Reisinger and F. Mavondo. 2006. Cultural Differences in Travel Risk Perception. Journal of Travel \& Tourism Marketing, vol. 20, no. (1), pp. 13-31. 